\title{
PELAKSANAAN KEMAHIRAN BERFIKIR ARAS TINGGI OLEH GURU DALAM PENGAJARAN DAN PEMBELAJARAN DI TADIKA
}

\section{The Implementation of Higher Order Thinking Skills by Teacher in Teaching and Learning at Kindergarten}

\author{
Suppiah Nachiappan ${ }^{1}$, Irna Patricia Julia ${ }^{2}$, Norazilawati Abdullah ${ }^{3}$, Sangkari Chandra \\ Sehgar ${ }^{4}$, Sandra Suffian ${ }^{5}, \&$ Noor Athirah Sukri ${ }^{6}$
}

Fakulti Pembangunan Manusia, Universiti Pendidikan Sultan Idris, Tanjong Malim, Perak, Malaysia ${ }^{1,2,3,4,5, \& 6}$

suppiah@fpm.upsi.edu.my¹, irnapatricia93@gmail.com²,nora@fpm.upsi.edu.my ${ }^{3}$, sangkarichandra@yahoo.com ${ }^{4}$, sandrasuffian@gmail.com ${ }^{5}, \&$ noorathirah91@yahoo.com 6

Received: 20 October 2019; Accepted: 25 November 2019; Published: 25 December 2019

DOI: https://doi.org/10.37134/jpak.vol8.4.2019

\begin{abstract}
ABSTRAK
Kajian ini bertujuan meneroka pelaksanaan Kemahiran Berfikir Aras Tinggi (KBAT) oleh guru dalam pengajaran dan pembelajaran (PdP) di tadika. Kajian ini dijalankan dalam bentuk kualitatif dengan menggunakan kaedah Hermeneutik dalam menganalisis dua belas sampel Rancangan Pengajaran Harian (RPH) sebagai teks, dan diinterpretasikan ke dalam bentuk metateks bagi memperoleh dapatan kajian. Sampel kajian dikumpul dari sebuah tadika swasta yang terletak di Ipoh, Perak. Kaedah Hermeneutik dapat mentafsir pengajaran guru sama ada mempunyai perkaitan dengan pelaksanaan KBAT, atau sebaliknya. Dapatan kajian menunjukkan guru sememangnya melaksanakan KBAT dalam PdP mereka di tadika. Antara elemen KBAT yang dilaksanakan oleh guru dalam PdP mereka ialah kemahiran mencerakinkan maklumat, menyiasat, mengaplikasi, menggambarkan, dan mengelaskan. Oleh itu, semoga pelaksanaan KBAT yang diamalkan guru dalam PdP mereka di tadika dapat membantu kanak-kanak untuk menguasai KBAT dengan baik.
\end{abstract}

Kata kunci: Kemahiran Berfikir Aras Tinggi, pengajaran dan pembelajaran, tadika, kaedah Hermeneutik

\begin{abstract}
This study aimed to analyze the implimentation of Higher Order Thinking Skills (HOTS) by teacher in teaching and learning $(T \& L)$ in kindergarten. This study was conducted in a qualitative design and Hermeneutic method by analyzing twelve samples Daily Lesson Plan (DLP) as text and interpreted into meta-text form to gain the results. The samples were collected from a private kindergarten located in Ipoh, Perak. Hermeneutic methods of teaching can interpret teacher teaching whether it is related with the application of current HOTS learning activities that conducted by teacher, or vice versa. The findings showed that teachers are actually implementing HOTS in their T\&L in kindergarten. Among the HOTS elements implemented by teachers in their T\&L are skills of informing, investigating, applying, describing, and classifying. Therefore, it is hoped that the implementation of HOTS by teachers in their PdP in kindergartens will help children to acquire HOTS.
\end{abstract}

Keywords: Higher Order Thinking Skills, teaching and learning, kindergarten, Hermeneutics method 


\section{PENGENALAN}

Kemahiran Berfikir Aras Tinggi (KBAT) ialah kebolehan seseorang individu untuk mengaplikasikan pengetahuan, kemahiran dan nilai yang telah dipelajari dalam membuat penaakulan dan refleksi bagi menyelesaikan masalah, membuat keputusan, berinovasi dan berupaya mencipta sesuatu (Lembaga Peperiksaan Malaysia, 2013). Ini menggambarkan penjanaan KBAT dalam kalangan kanak-kanak memerlukan proses kemahiran berfikir secara intelek dengan pemikiran yang meluas serta mendalam sama ada mencari makna dan pemahaman terhadap sesuatu isu yang telah dipelajari, membuat pertimbangan dan keputusan atau menyelesaikan masalah.

Pengaplikasian KBAT dalam pendidikan di Malaysia bermula sejak tahun 1988 melalui pengenalan Kurikulum Bersepadu Sekolah Menengah (KBSM). Walau bagaimanapun, KBAT hanya diberi keutamaan melalui Malaysian Education Blueprint (MEB) 2013-2025 yang membawa kepada transformasi dalam sistem pendidikan. Transformasi ini telah menekankan KBAT dalam pendidikan Malaysia bermula dari peringkat tadika hingga ke peringkat pengajian tinggi. Guru diberi latihan dan kursus khas bagi menjalankan proses pengajaran dan pembelajaran (PdP) berlandaskan KBAT supaya dapat melaksanakannya ke dalam diri kanakkanak. Pelaksanaan KBAT dalam kalangan kanak-kanak tadika adalah penting supaya kanakkanak dapat dibiasakan dengan pemikiran aras tinggi sejak kecil lagi. Oleh itu, kajian ini dijalankan untuk meneroka pelaksanaan KBAT oleh guru dalam PdP di tadika.

\section{METODOLOGI}

Kajian ini menggunakan pendekatan kualitatif yang melibatkan penggunaan fakta, maklumat, pernyataan, ulasan, tanggapan dan seumpamanya. Sumber data yang boleh diperoleh dalam kajian secara kualitatif adalah dalam bentuk buku, majalah, jurnal, wawancara dan pemerhatian. Selain itu, kajian secara kualitatif ini adalah bersifat deskriptif kerana data yang dikumpulkan berkonsepkan pengucapan kata-kata, gambar kajian dan tidak melibatkan angka atau nombor.

Dalam kajian ini, data diperoleh melalui Rancangan Pengajaran Harian (RPH) yang dianalisis menggunakan kaedah Hermeneutik. Ini kerana kaedah Hermeneutik merupakan salah satu cabang daripada kajian secara kualitatif yang dapat menganalisis dan menginterpretasikan makna RPH bagi menjawab soalan-soalan kajian ini. Sampel kajian terdiri daripada hasil pemerhatian dan analisis dokumen terhadap RPH daripada sebuah tadika swasta di Ipoh, Perak.

\section{DAPATAN KAJIAN}

Dalam proses PdP (Benih Kacang Hijau), guru mendapati 100 peratus kanak-kanak dapat menerangkan semula proses tumbesaran biji benih kacang hijau berdasarkan tayangan video. Dalam aspek pelaksanaan KBAT, kanak-kanak dapat menganalisis maklumat dengan mencerakinkan maklumat (memadankan kad imbasan proses kitaran hidup kacang hijau) dengan pasangan tanpa bimbingan guru.Selain itu, kanak-kanak dapat menyiasat setiap fungsi bahagian-bahagian pokok untuk tumbesaran yang baik dengan bimbingan guru. Jadual 1 berikut menunjukkan analisis pelaksanaan KBAT dalam proses PdP (Benih Kacang Hijau); 
Jadual 1

Analisis Pelaksanaan KBAT dalam Proses PdP (Benih Kacang Hijau) melalui Kaedah Hermeneutik

\begin{tabular}{|c|c|c|c|}
\hline \multicolumn{2}{|c|}{ Teks RPH Asal } & $\begin{array}{l}\text { Respon Murid } \\
\text { (Lisan/ Hasil Kerja } \\
\text { Murid) }\end{array}$ & $\begin{array}{l}\text { Interpretasi Kemahiran } \\
\text { Berfikir Aras Tinggi } \\
\text { (KBAT) Dalam PDP } \\
\text { Prasekolah bagi Tunjang } \\
\text { Sains dan Teknologi } \\
\text { Melalui Kaedah } \\
\text { Hermeneutik }\end{array}$ \\
\hline $\begin{array}{l}\text { RPH } \\
\begin{array}{l}\text { Modul } \\
\text { bertema } \\
\text { (Sains) }\end{array} \\
\text { Set Induksi } \\
\text { (5 minit) } \\
\text { Tema: } \\
\text { Pokok } \\
\text { Kacang } \\
\text { Hijau }\end{array}$ & $\begin{array}{l}29 / 7 / 16 / \text { Jumaat } \\
\text {-Teacher take } \\
\text { out all the } \\
\text { green bean } \\
\text { plan. } \\
\text {-Teacher ask } \\
\text { children } \\
\text { watering their } \\
\text { own green } \\
\text { bean plant. }\end{array}$ & $\begin{array}{l}\text {-Children watering } \\
\text { their own green bean } \\
\text { plan. Children put } \\
\text { water inside small } \\
\text { bowl. }\end{array}$ & $\begin{array}{l}\text {-Sebagai induksi, guru } \\
\text { meminta murid sendiri } \\
\text { menyiram tanaman pokok } \\
\text { kacang hijau mereka di } \\
\text { dalam bekas masing- } \\
\text { masing dengan bimbingan. } \\
\text { Tahap pemikiran yang } \\
\text { diterapkan adalah menilai, } \\
\text { iaitu murid membuat } \\
\text { keputusan yang betul bagi } \\
\text { memastikan kuantiti air } \\
\text { yang digunakan untuk } \\
\text { menyiram pokok kacang } \\
\text { hijau dengan sesuai. }\end{array}$ \\
\hline $\begin{array}{l}\text { Langkah } 1 \\
\text { (10 minit) }\end{array}$ & $\begin{array}{l}\text {-Teacher called } \\
\text { up one by one } \\
\text { children to } \\
\text { measure the } \\
\text { bean and } \\
\text { record the } \\
\text { height in the } \\
\text { Science Book. } \\
\text {-Teacher guide } \\
\text { one by one }\end{array}$ & $\begin{array}{l}\text {-Children wait for } \\
\text { their name called up } \\
\text { by teacher to } \\
\text { measure bean and } \\
\text { record the height in } \\
\text { the Science Book. } \\
\text {-Children measure } \\
\text { the green bean using } \\
\text { string and ruler with } \\
\text { teacher guidance. }\end{array}$ & $\begin{array}{l}\text {-Dalam langkah satu, guru } \\
\text { membuat aktiviti } \\
\text { pengukuhan iaitu } \\
\text { mengarahkan setiap murid } \\
\text { mengukur ketinggian } \\
\text { kacang hijau menggunakan } \\
\text { benang, dan pembaris } \\
\text { dengan bimbingan guru. } \\
\text {-Tahap pemikiran seperti } \\
\text { menganalisis murid dapat }\end{array}$ \\
\hline
\end{tabular}

\begin{tabular}{|l|l|l|l|}
\hline & $\begin{array}{l}\text { children } \\
\text { measure the } \\
\text { green bean } \\
\text { plant using } \\
\text { string and } \\
\text { ruler. }\end{array}$ & $\begin{array}{l}\text {-Children write the } \\
\text { height of their green } \\
\text { bean plants foloow } \\
\text { the day in cm inside } \\
\text { their on Science } \\
\text { Book using pencil. } \\
\text {-Teacher let } \\
\text { children to } \\
\text { write the } \\
\text { height of green } \\
\text { bean plants } \\
\text { follow the day } \\
\text { in cm inside } \\
\text { the Science } \\
\text { Book. }\end{array}$ & $\begin{array}{l}\text { diterapkan melalui aktiviti } \\
\text { iaitu murid mengukur } \\
\text { ketinggian pokok kacang } \\
\text { hijau sejak hari pertama } \\
\text { eksperimen dijalankan } \\
\text { sehingga hari yang ketujuh. } \\
\text { Murid akan mencatatkan } \\
\text { dan merekod ketinggian } \\
\text { pokok kacang hijau mereka } \\
\text { dalam Buku Sains mereka. }\end{array}$ \\
& & \\
\hline
\end{tabular}




\begin{tabular}{|c|c|c|c|}
\hline $\begin{array}{l}\text { Langkah } 2 \\
\text { (20 minit) }\end{array}$ & $\begin{array}{l}\text {-Teacher give } \\
\text { all children } \\
\text { their own } \\
\text { green bean } \\
\text { plant. } \\
\text {-Teacher let } \\
\text { children see } \\
\text { their plant have } \\
\text { root come out } \\
\text { or still not yet, } \\
\text { on the day } 4 \text {. } \\
\text {-Teacher ask } \\
\text { one by one } \\
\text { children: } \\
\text { Question: Did } \\
\text { your green } \\
\text { bean plant root } \\
\text { come out or } \\
\text { not? Why plant } \\
\text { need root to } \\
\text { live? }\end{array}$ & $\begin{array}{l}\text {-All children wait } \\
\text { their turn and listen } \\
\text { to teacher. } \\
\text {-Children observe } \\
\text { their own green bean } \\
\text { plant see whether } \\
\text { the root came out } \\
\text { already or not yet. } \\
\text { Children response :- } \\
\text { 1. "My one got root } \\
\text { came out already, } \\
\text { teacher" } \\
\text { 2. "Plant need root } \\
\text { to live because root }\end{array}$ & $\begin{array}{l}\text {-Dalam langkah kedua ini, } \\
\text { guru meminta murid } \\
\text { memerhatikan hasil } \\
\text { eksperimen mereka dengan } \\
\text { melihat perubahan pokok } \\
\text { kacang hijau masing- } \\
\text { masing. Tahap pemikiran } \\
\text { yang diterapkan dalam } \\
\text { langkah yang kedua ini } \\
\text { adalah menganalisis iaitu } \\
\text { murid memeriksa } \\
\text { perubahan pokok kacang } \\
\text { hijau mereka sama ada } \\
\text { akar pokok kacang hijau } \\
\text { telah keluar atau pun } \\
\text { pokok kacang hijau mereka } \\
\text { mati semasa eksperimen } \\
\text { dijalankan. }\end{array}$ \\
\hline
\end{tabular}

\begin{tabular}{|c|c|c|c|}
\hline & & $\begin{array}{l}\text { absorb water to } \\
\text { continued lives." }\end{array}$ & \\
\hline $\begin{array}{l}\text { Penutup } \\
\text { (5 minit) }\end{array}$ & $\begin{array}{l}\text {-Teacher ask } \\
\text { children come } \\
\text { infront and tell } \\
\text { the name of } \\
\text { the body part } \\
\text { of plant on } \\
\text { their green } \\
\text { bean plant and } \\
\text { spell it with } \\
\text { right: } \\
\text { - Leaves } \\
\text { - Stem } \\
\text { - Root }\end{array}$ & $\begin{array}{l}\text {-Children answer } \\
\text { politely. Children } \\
\text { name all body part } \\
\text { of the green bean } \\
\text { plant. Children } \\
\text { spelled the body part } \\
\text { of green bean } \\
\text { correctly. } \\
\text { - Leaves } \\
\text { - Stem } \\
\text { - Root }\end{array}$ & $\begin{array}{l}\text {-Sebagai sesi PdP, guru } \\
\text { mengimbas kembali apa } \\
\text { yang telah disampaikan } \\
\text { dengan menyoal murid } \\
\text { untuk memberitahu setiap } \\
\text { bahagian pokok kacang } \\
\text { hijau dan menyuruh murid } \\
\text { mengeja dengan tepat. } \\
\text {-Dari segi tahap pemikiran } \\
\text { murid dapat } \\
\text { mengaplikasikan } \\
\text { maklumat dengan } \\
\text { mengguna pakai } \\
\text { pengetahuan yang telah } \\
\text { dipelajari pada PdP yang } \\
\text { sebelumnya. }\end{array}$ \\
\hline
\end{tabular}

Dalam proses PdP (Salad) pula, tahap pemikiran KBAT yang dilaksanakan oleh guru ialah kanak-kanak dapat mengaplikasi maklumat, iaitu kanak-kanak menggambarkan jenis buah-buahan yang mereka tahu sebelum ini. Seterusnya, aktiviti tambahan guru untuk memperkukuhkan KBAT kanak-kanak adalah dengan menunjukkan tayangan bergambar mengenai buah-buahan tempatan dan buah-buahan bukan tempatan. Berdasarkan tahap pemikiran, kanak-kanak dapat mengaplikasikan maklumat dengan mengelaskan buahbuahan sama ada buah-buahan tempatan atau buah-buahan bukan tempatan dengan tepat. Analisis pelaksanaan KBAT dalam proses PdP (Salad) ditunjukkan dalam Jadual 2 berikut; 
Jadual 2

Analisis Pelaksanaan KBAT dalam Proses PdP (Salad) melalui Kaedah Hermeneutik

\begin{tabular}{|c|c|c|c|}
\hline \multicolumn{2}{|c|}{ Teks RPH Asal } & $\begin{array}{l}\text { Respon Murid } \\
\text { (Lisan/ Hasil Kerja } \\
\text { Murid) }\end{array}$ & $\begin{array}{l}\text { Interpretasi } \\
\text { Kemahiran Berfikir } \\
\text { Aras Tinggi (KBAT) } \\
\text { Dalam PdP Prasekolah } \\
\text { bagi Tunjang } \\
\text { Perkembangan Fizikal } \\
\text { dan Estetika Melalui } \\
\text { Kaedah Hermeneutik }\end{array}$ \\
\hline $\begin{array}{l}\text { RPH } \\
\text { Modul } \\
\text { bertema } \\
\text { (Penjagaan } \\
\text { Kesihatan) } \\
\text { Set induksi } \\
\text { (5 minit) } \\
\text { Terna : } \\
\text { Salad }\end{array}$ & $\begin{array}{l}23 / 9 / 16 / \text { Jumaat } \\
\text {-Teacher ask } \\
\text { one by one } \\
\text { children to } \\
\text { stand up. } \\
\text { Teacher ask } \\
\text { question to } \\
\text { children } \\
\text { Question C Can } \\
\text { you please tell } \\
\text { to teacher the } \\
\text { fruit that you } \\
\text { know? }\end{array}$ & $\begin{array}{l}\text {-Children gives } \\
\text { response, stand up } \\
\text { and answer teacher. } \\
\text { Answer, apple, } \\
\text { strawberry, durian, } \\
\text { banana, papaya, etc. }\end{array}$ & $\begin{array}{l}\text {-Dalam set induksi, } \\
\text { tahap permikiran yang } \\
\text { diterapkan adalah } \\
\text { mengaplikasi maklumat } \\
\text { iaitu murid } \\
\text { menggambarkan jenis } \\
\text { buah-buahan yang } \\
\text { mereka tahu sebelum } \\
\text { ini. } \\
\text { Jawapan murid. Epal, } \\
\text { strawberry, durian, } \\
\text { pisang dan betik. }\end{array}$ \\
\hline $\begin{array}{l}\text { Langkah } 1 \\
\text { (10 minit) }\end{array}$ & $\begin{array}{l}\text {-Teacher show } \\
\text { a slide show } \\
\text { about Local and } \\
\text { Imported Fruits. } \\
\text { - Local } \\
\text { fruits: } \\
\text {-Rambutan, } \\
\text { durian, } \\
\text { mangoestee }\end{array}$ & $\begin{array}{l}\text {-Children pay } \\
\text { attention and watch } \\
\text { the picture Local and } \\
\text { Imported Fruits } \\
\text { carefully. } \\
\text { - Local fruits : } \\
\text {-Rambutan, } \\
\text { durian, } \\
\text { mangoesteen, }\end{array}$ & $\begin{array}{l}\text {-Dalam langkah } 1 \text {, guru } \\
\text { mengukuhkan } \\
\text { kefahaman murid } \\
\text { dengan menunjukkan } \\
\text { tayangan bergambar } \\
\text { mengenai Buah-buahan } \\
\text { Tempatan dan Import. } \\
\text {-Berdasarkan tahap } \\
\text { pemikiran, murid dapat }\end{array}$ \\
\hline & $\begin{array}{l}\text { n, papaya, } \\
\text { starfruit, } \\
\text { banama, } \\
\text { mango. } \\
\text { - Importa } \\
\text { nt fruits } \\
\text {-Strawberry, } \\
\text { grape, } \\
\text { apple, } \\
\text { orange, } \\
\text { mulberry.pe } \\
\text { ar. kiwi, } \\
\text { cherry. } \\
\\
\text { - Teacher } \\
\text { explain to } \\
\text { children that are } \\
\text { so many type of } \\
\text { fruit. Teacher } \\
\text { going to } \\
\text { categorized all } \\
\text { fruit in two } \\
\text { types that is } \\
\text { (Local fruit and } \\
\text { Import fruits). }\end{array}$ & $\begin{array}{l}\text { papaya, starfruit, } \\
\text { banana, mango. } \\
\text { - Important } \\
\text { - fruits : } \\
\text { grape, apple, } \\
\text { orange, mulberry, } \\
\text { pear, kiwi, cherry. } \\
\text { - Children pay } \\
\text { attention and listen to } \\
\text { teacher explanation. } \\
\text { - Teacher going to } \\
\text { categorized all fruit } \\
\text { in two types that is } \\
\text { I ocal fruit and } \\
\text { Import fruits). } \\
\text { Local fruit (1ocal fruit } \\
\text { is a fruit that is } \\
\text { produced from the } \\
\text { country itself. Local } \\
\text { fruit is suited to the } \\
\text { climate (tropical } \\
\text { rainforest climate- } \\
\text { being hot and humid) } \\
\text { in our country. }\end{array}$ & $\begin{array}{l}\text { mengaplikasikan } \\
\text { maklumat dengan } \\
\text { mengelaskan buah- } \\
\text { buahan sama ada buah- } \\
\text { buahan tersebut } \\
\text { tergolong dalam buah- } \\
\text { buahan tempatan atau } \\
\text { buah-buahan import } \\
\text { dengan teliti. } \\
\text { - Buah-buahan Tempatan } \\
\text { = } \\
\text { Rambutan, durian, } \\
\text { manggis, betik, } \\
\text { belimbing, mangga. } \\
\text {-Buah-buahan Import } \\
\text { Strawberry, anggur, } \\
\text { epal, oren, mulberi, } \\
\text { pear, kiwi, ceri. } \\
\text {-Melalui penerangan } \\
\text { guru mengenai jenis- } \\
\text { jenis buaham, tahap } \\
\text { pemikiran murid dalam } \\
\text { menilai sesuatu } \\
\text { maklumat dapat, } \\
\text { diterapkan iaitu, gnurid }\end{array}$ \\
\hline
\end{tabular}




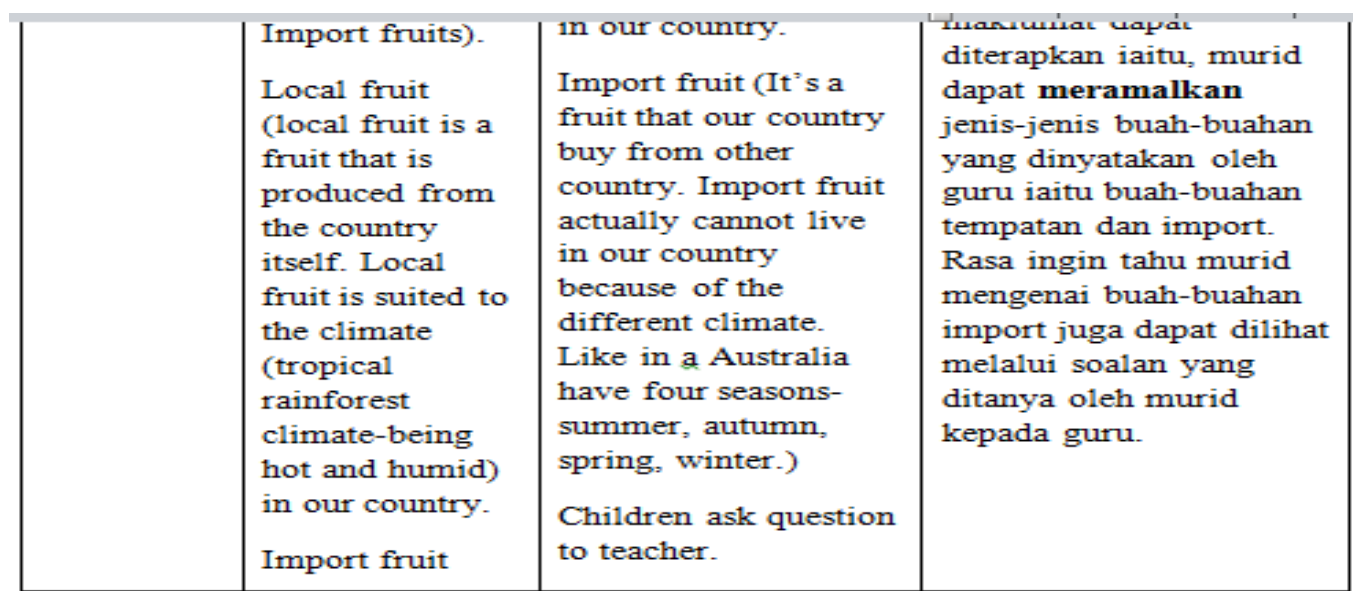

\begin{tabular}{|c|c|c|c|}
\hline & $\begin{array}{l}\text { (It's a fruit that } \\
\text { our country buy } \\
\text { from other } \\
\text { country. Import } \\
\text { fruit actually } \\
\text { cannot live in } \\
\text { our country } \\
\text { because of the } \\
\text { different } \\
\text { climate. Like in } \\
\text { a Australia have } \\
\text { four seasons- } \\
\text { summer, } \\
\text { autumn, spring, } \\
\text { winter.) }\end{array}$ & $\begin{array}{l}\text {-Question : Teacher, } \\
\text { what is the import } \\
\text { fruit? Why we need } \\
\text { buy fruit from other } \\
\text { country? }\end{array}$ & \\
\hline $\begin{array}{l}\text { Langkah } 2 \\
\text { (20 minit) }\end{array}$ & $\begin{array}{l}\text {-Teacher ask } \\
\text { children to do a } \\
\text { project (a salad } \\
\text { fruit). } \\
\text {-Teacher show } \\
\text { a material that } \\
\text { be used (knives } \\
\text { plastic, } \\
\text { paper/polisterin } \\
\text { e plate, plastic } \\
\text { container, } \\
\text { plastic spoon, } \\
\text { tissue paper) to } \\
\text { prepare a salad. } \\
\text {-Teacher show } \\
\text { a fruit that } \\
\text { already been } \\
\text { categorized and } \\
\text { named it for } \\
\text { every fruit } \\
\text { container to a } \\
\text { children. }\end{array}$ & $\begin{array}{l}\text {-Children feel great } \\
\text { and excited. } \\
\text {-Children see } \\
\text { carefully and pay } \\
\text { attention to teacher. } \\
\text {-Children understand } \\
\text { and easy scoop the } \\
\text { fruits later because } \\
\text { got labeling for every } \\
\text { container. } \\
\text {-Children put the } \\
\text { thing on the table and } \\
\text { listen to teacher. } \\
\text {-Children go infront } \\
\text { take a fruit inside } \\
\text { their own plastic } \\
\text { container. } \\
\text {-Children cut the fruit } \\
\text { inside the paper plate } \\
\text { nicely using plastic }\end{array}$ & $\begin{array}{l}\text {-Dalam langkah 2, guru } \\
\text { membuat aktiviti iaitu } \\
\text { aktiviti Salad Buah- } \\
\text { buahan. Berdasarkan } \\
\text { tahap pemikiran, murid } \\
\text { mengaplikasi maklumat } \\
\text { baharu dengan } \\
\text { menunjuk kemahiran } \\
\text { menggunakan motor } \\
\text { halus dalam memotong } \\
\text { buah-buahan } \\
\text { menggunakan pisau } \\
\text { plastik dengan berhati- } \\
\text { hati melalui bimbingan } \\
\text { guru. } \\
\text {-Melalui aktiviti Salad } \\
\text { Buah, murid dapat } \\
\text { menganalisis dengan } \\
\text { membezakan sendiri } \\
\text { jenis buah-buahan } \\
\text { tempatan dan buahan } \\
\text { import yang telah }\end{array}$ \\
\hline
\end{tabular}




\begin{tabular}{|c|c|c|c|}
\hline & $\begin{array}{l}\text {-Teacher } \\
\text { distribute all } \\
\text { equipment used } \\
\text { on children. The } \\
\text { teacher asks the } \\
\text { children to be } \\
\text { careful to use a } \\
\text { plastic knife. } \\
\text { - Teacher ask } \\
\text { children cut the } \\
\text { fruit nicely. } \\
\text { - Teacher put a } \\
\text { mayonis to } \\
\text { every children } \\
\text { who already } \\
\text { done cut all } \\
\text { their fruit. } \\
\text { Teacher ask } \\
\text { children stir and } \\
\text { mix up their } \\
\text { fruit together } \\
\text { with the salad. }\end{array}$ & $\begin{array}{l}\text { knives. } \\
\text {-Children got } \\
\text { mayonis from } \\
\text { teacher. Children stir } \\
\text { and mix up the fruit } \\
\text { inside their container } \\
\text { use spoon. } \\
\text {-Children clean the } \\
\text { spoon, plastic knife } \\
\text { and wipe the table } \\
\text { use tissue. } \\
\text { a } \\
\text { and }\end{array}$ & $\begin{array}{l}\text { dipotong menggunakan } \\
\text { pisau. Murid juga dapat } \\
\text { merasai sendiri } \\
\text { pengalaman membuat } \\
\text { salad dengan bimbingan } \\
\text { guru. }\end{array}$ \\
\hline $\begin{array}{l}\text { Penutup } \\
\text { ( } 5 \text { minit) }\end{array}$ & $\begin{array}{l}\text {-Teacher ask } \\
\text { children sing } \\
\text { and dance a } \\
\text { Banana Song } \\
\text { together. }\end{array}$ & $\begin{array}{l}\text {-Children excited } \\
\text { dancing a Banana } \\
\text { Song with teacher } \\
\text { and feel fun. }\end{array}$ & $\begin{array}{l}\text {-Sebelum tamat PdP, } \\
\text { guru bersama-sama } \\
\text { murid menari dan } \\
\text { menyanyikan "Banana } \\
\text { Song". }\end{array}$ \\
\hline
\end{tabular}

\section{PERBINCANGAN}

Kajian ini dapat meneroka pelaksanaan KBAT oleh guru dalam PdP di tadika. Antara elemen KBAT yang dilaksanakan oleh guru dalam PdP mereka ialah kemahiran mencerakinkan maklumat, menyiasat, mengaplikasi, menggambarkan, dan mengelaskan. Guru perlu bijak, kreatif dan sentiasa menemui teknik dan kaedah yang baharu dalam bidang pendidikan awal kanak-kanak untuk melaksanakan KBAT dalam PdP mereka.

Ibu bapa juga memainkan peranan penting dalam mendidik dan menggalakkan proses berfikir aras tinggi terhadap anak-anak mereka. Ibu bapa merupakan orang pertama yang menanam dan memberi dorongan serta bimbingan dalam bidang akademik di rumah. Menurut Murphy, Rowe, Ramani dan Silverman (2014), kanak-kanak mula memperoleh keupayaan untuk memproses maklumat dan untuk membezakan antara alternatif yang pada usia yang sangat muda melalui interaksi dan pengalaman dengan orang lain di rumah dan komuniti mereka. Pengurus atau pengusaha tadika juga perlu memainkan peranan penting untuk menekankan aspek KBAT dalam kalangan kanak-kanak tadika. 


\section{KESIMPULAN}

Keseluruhannya, kajian ini membuktikan guru sememangnya melaksanakan KBAT dalam PdP mereka di tadika. Ini amat penting kerana KBAT perlu dipupuk dan diamalkan sejak awal umur kanak-kanak lagi sama ada bermula di rumah mahupun di tadika. Justeru, semoga pelaksanaan KBAT yang diamalkan guru dalam PdP mereka di tadika dapat membantu kanakkanak untuk menguasai KBAT dengan baik.

\section{BIBLIOGRAFI}

Agrey, L. G. (2014). Opportunities and possibilities : Philosophical hermeneutic and the educationanl researcher. Universal Jurnal of Educational Research, 2(4), 396-412.

Chang, J. (2010). Hermenutic inquiry: A Research approach for postmodern therapists. $\begin{array}{llll}\text { Journal of Systemic } & \text { Therapies, }\end{array}$ http://dx.doi.org/10.1521/jsyt.2010.29.1.19.

Chittenden, E., \& Jones, J. (1999). Dialogue on early chilhood science, mathematics \& technology education/first experiences in science, mathematics \& technology. American Association For The Advancement Of Science (AAAS).

Dilthey. (1976). The rise of hermeneutics: The hermeneutic tradition. Cambridge Universiti Press.

Flavell, J. H. (1976). The development psychology of Jean Piaget. D. Van Nostrand.

Huffman, K. (2000). Living psychology. New York: John Wiley \& Sons, Inc.

Kementerian Pelajaran Malaysia. (2010). Kurikulum Standard Prasekolah Kebangsaan. Putrajaya: Bahagian Pembangunan Kurikulum, Penulis.

Kementerian Pendidikan Malaysia. (2014). Elemen KBAT dalam kurikulum. Putrajaya: Bahagian Pembangunan Kurikulum, Penulis.

Kementerian Pendidikan Malaysia. (2016). Kurikulum Standard Prasekolah Kebangsaan: Pendidikan Prasekolah. Putrajaya: Bahagian Pembangunan Kurikulum, Penulis.

Lembaga Peperiksaan Malaysia. (2013). Elemen kemahiran berfikir aras tinggi (KBAT) dalam instrumen pentaksiran. Putrajaya: Kementerian Pendidikan Malaysia.

Loganathan, K. (1992). Hermeneutic analysis of discourse. Thiruvananthapuram: International School of Dravidian Linguistics.

Mark, K. M., \& Quillan et. al. (2007). A guide to early childhood program development. State Board Of Education. Diperoleh semula daripada http://www.sde.ct.gov/sde/lib/sde/PDF/DEPS/Early/early_childhood_guide.pdf.

Mueller, V. K. (1997). The hermeneutic reader. New York: The Continuum Publishing Company.

Noraliza Idris. (2013). Analisis aplikasi kognisi dalam pengajaran dan pembelajaran awal kanak-kanak melalui Tunjang Sains dan Teknologi dalam Kurikulum Standard Prasekolah Kebangsaan (KSPK). Tanjong Malim: Universiti Pendidikan Sultan Idris (Tesis Yang Tidak Diterbitkan).

Norwahida Mokhtar. (2013). Analisis Aplikasi kognisi dalam pengajaran dan pembelajaran awal kanak-kanak melalui Tunjang Fizikal dan Estetika dalam Kurikulum Standard Prasekolah Kebangsaan (KSPK). Tanjong Malim: Universiti Pendidikan Sultan Idris (Tesis Yang Tidak Diterbitkan).

Piaget, J. (1970). Piaget's theory. In Mussen, P. H. (Ed.). Carmichael's handbook of child.

Schleiermacher F. D. E. (1997). Hermeneutics: The handwritten manuscripts, ed.heinzkimmerle. Terj: James Duke \& Jack Forstman. Montana. Scholars Press. 
Smith, D. G. (2010). Hermeneutic inquiry. In C. Kridel (Ed.). Encyclopedia Of curriculum studies (Vol. 1, pp. 432-436), Thousand Oaks, CA: SAGE.

Sumaryono, E. (1999). Hermeneutik sebuah metode filsafat. Yogyakarta: Kanisius Sdn. Bhd.

Suppiah Nacchiappan. (2003). Proses kognitif dalam penulisan esei melalui analisis hermeneutik. Universiti Sains Malaysia (Tesis Yang Tidak Diterbitkan).

Suppiah Nachiappan. (2013). Proses kognisi dan afeksi: Kaedah pedagogi hermeneutik dan interpretasi. Tanjong Malim: Penerbit Universiti Pendidikan Sultan Idris.

Suppiah Nachiappan. (2014a). Panduan pendidikan awal kanak-kanak: Teori, model, kaedah dan aktiviti ke arah perkembangan kognisi. Tanjong Malim: Penerbit Universiti Pendidikan Sultan Idris.

Suppiah Nachiappan. (2014b). Gaya bahasa dan proses kognisi: Kaedah pedagogi hermeneutik dan interpretasi. Tanjong Malim: Penerbit Universiti Pendidikan Sultan Idris.

Trundle, K. C. (2009). Teaching science during the early childhood years. The Ohio State University. Diperoleh semula daripada www.ngsp.com/Portals/0/.../SCL220429A_AM_Trundle.pdf. 